\title{
A case of lissencephaly in a 5-month-old infant
}

\author{
Adeel Ejaz Syed
}

Department of Paediatrics, Princess Alexandra Hospital, Essex, UK

\section{Correspondence to} Dr Adeel Ejaz Syed, adeelsyed786@gmail.com

Accepted 8 January 2015
CrossMark

To cite: Syed AE. BMJ Case Rep Published online: [please include Day Month Year] doi:10.1136/bcr-2014206522

\section{DESCRIPTION}

A 5-month-old full-term male patient, born of a nonconsanguineous marriage presented to A\&E department following parental concerns about abnormal movements and developmental regression.

Development halted at 4 months of age. The patient increasingly showed episodes with flickering of eyes and tonic movements followed by postictal behaviour.

He stopped fixing and following, stopped responding to loud noises, stopped reaching out for objects, and had stopped babbling or making any noises, all of which he had been doing previously. Examination revealed a child with a frog-like posture who appeared very floppy, and with a relatively small head circumference of $41.7 \mathrm{~cm}$ (9th centile). Initial blood examinations revealed no significant abnormality. An EEG indicated hypsarrhythmia and a brain MRI was performed. This showed

1. Very few sulci with thick cortex;

2. Some gyri formation along frontal and temporal lobes (pachygyria);

3. Circumferential band of high signal change in parieto-occipital cortex.

This was all consistent with lissencephaly type 1 , and genetic tests later confirmed a corresponding LIS1 c. 1050delG mutation. Owing to poor effect with other antiepileptics, Vigabatrin was started in this patient to control his multiple seizures.

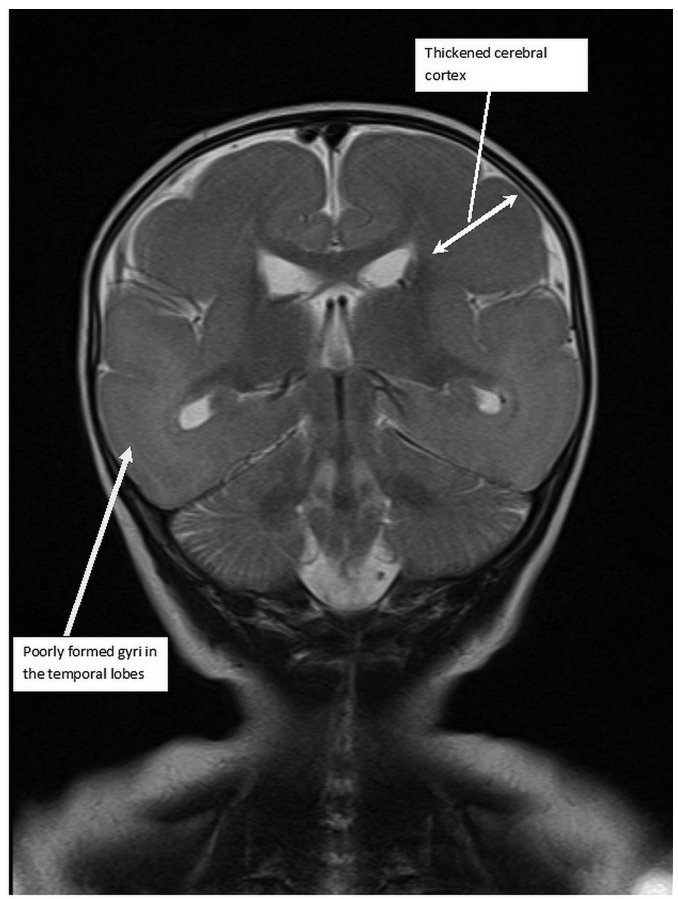

Figure 1 T2-weighted coronal image showing poorly formed gyri in the temporal lobes and a thickened cerebral cortex.

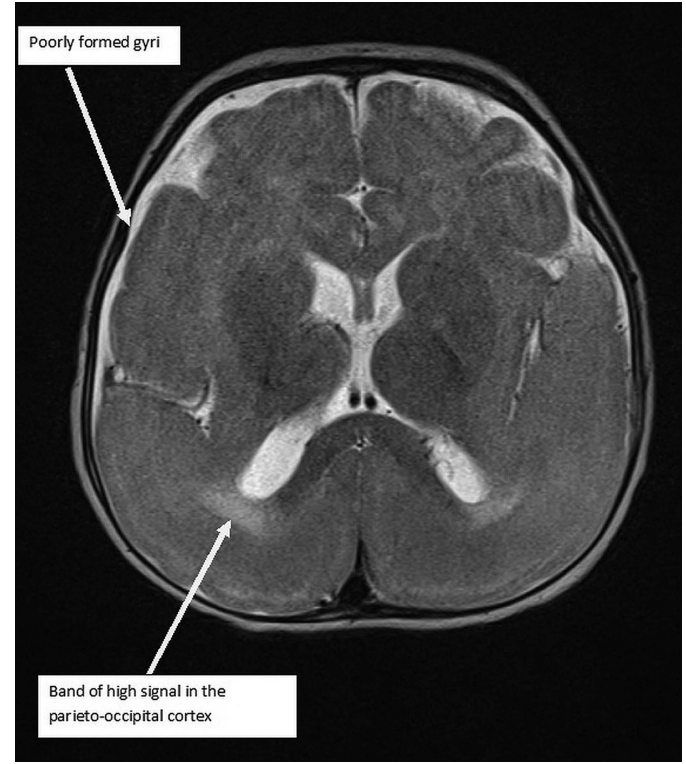

Figure 2 T2-weighted axial image showing poorly formed gyri and a band of high signal in the parieto-occipital cortex.

Lissencephaly means smooth brain, and is caused by a neuronal migration defect ${ }^{1}$ resulting in a severe lack of gyrus and sulcus formation. LIS1-associated lissencephaly includes MillerDieker syndrome, isolated lissencephaly sequence (ILS) and others, ${ }^{2}$ which can be established by using fluorescence in situ hybridisation. Prognosis is relatively poor with most children passing away by age 10 . Figures $1-3$ show the various MRIs and their sequences.

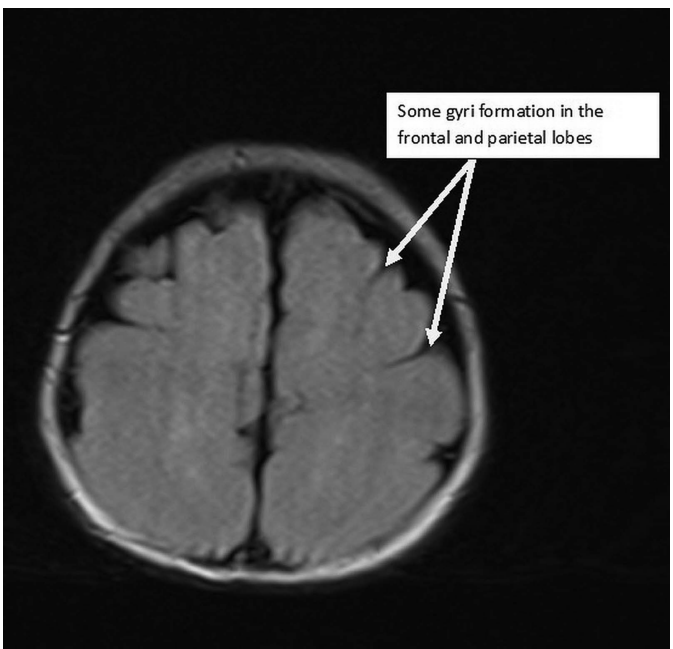

Figure 3 Axial fluid-attenuated inversion recovery image showing some gyri formation in the frontal and parietal lobes. 
Learning points

- Lissencephaly (smooth brain) represents a group of disorders with neuronal migration defects that are characterised by severely reduced gyral and sulcal formation (aygria or pachygyria).

- Lissencephaly has no cure, and management is largely via supportive treatment.

Competing interests None.
Patient consent Obtained.

Provenance and peer review Not commissioned; externally peer reviewed.

\section{REFERENCES}

1 Wynshaw-Boris A. Lissencephaly and LIS1: insights into the molecular mechanisms of neuronal migration and development. Clin Genet 2007:72:296-304.

2 Dobyns WB, Das S. LIS1-associated lissencephaly/subcortical band heterotropia. 2009 Mar 3 [Updated 14 Aug 2014]. In: Pagon RA, Adam MP, Ardinger HH et al, eds. GeneReviews ${ }^{\circledR}$ [Internet]. Seattle, WA: University of Washington, 1993-2014. http:/l www.ncbi.nlm.nih.gov/books/NBK5189

Copyright 2015 BMJ Publishing Group. All rights reserved. For permission to reuse any of this content visit http://group.bmj.com/group/rights-licensing/permissions.

BMJ Case Report Fellows may re-use this article for personal use and teaching without any further permission.

Become a Fellow of BMJ Case Reports today and you can:

- Submit as many cases as you like

- Enjoy fast sympathetic peer review and rapid publication of accepted articles

- Access all the published articles

- Re-use any of the published material for personal use and teaching without further permission

For information on Institutional Fellowships contact consortiasales@bmjgroup.com

Visit casereports.bmj.com for more articles like this and to become a Fellow 